\title{
Dysexecutive Syndrome in a Patient with Wilson’s Disease
}

\author{
Nataly Gutiérrez-Ávila ${ }^{1}$, Jimmy Zúñiga-Márquez ${ }^{1}$, Natalia Burgos-Torres ${ }^{1}$, \\ John Arias-Valencia ${ }^{1}$, Patricia Quintero-Cusguen ${ }^{2}$, Rocio Acosta-Barreto ${ }^{1}$ \\ ${ }^{1}$ Faculty of Psychology, San Buenaventura Bogotá University, Neuropsychology Master and \\ Specialization Program, Bogotá, Colombia \\ ${ }^{2}$ Universitary Hospital La Samaritana, Bogotá, Colombia \\ Email: rocioacosta93@yahoo.com, psnatalygutierrez@hotmail.com
}

Received August 30 ${ }^{\text {th }}$, 2013; revised September 28 $8^{\text {th }}$, 2013; accepted October 25 ${ }^{\text {th }}, 2013$

\begin{abstract}
Copyright (C 2014 Nataly Gutiérrez-Ávila et al. This is an open access article distributed under the Creative Commons Attribution License, which permits unrestricted use, distribution, and reproduction in any medium, provided the original work is properly cited. In accordance of the Creative Commons Attribution License all Copyrights (c) 2014 are reserved for SCIRP and the owner of the intellectual property Nataly Gutiérrez-Ávila et al. All Copyright $(\subseteq 2014$ are guarded by law and by SCIRP as a guardian.
\end{abstract}

Clinical Case Report: This paper presents the alterations and deficits in executive functions of a 33 years old man with Wilson's disease, patient at the Hospital Universitario La Samaritana in Bogotá, who in 2011 was diagnosed with cerebellar ataxia, and beginning to show a clinical picture of dysarthria and generalized motor difficulties. The presence of neuropsychological disorders, as well as the results obtained by Magnetic Resonance Imaging (MRI) of the brain and optical exam (Kayser-Fleischer rings) confirmed the diagnosis of Wilson's disease. Results and Conclusion: The neuropsychological profile of the patient showed alterations of attention and mnemonic processes associated with frontal functioning, as well as slowing-down of motor activities and low speed in processing information. The assessment of executive functions revealed impairment in cognitive flexibility, impulsivity and disinhibition, as well as difficulties in the process of planning, organizing and monitoring. All of these features indicated the presence of a dysexecutive syndrome in the patient and correlated with the results obtained by MRI.

Keywords: Wilson’s Disease; Executive Functions; Neuropsychological Profile; Dysexecutive Syndrome

\section{Introduction}

Wilson disease (WD), also known as hepatolenticular degeneration, is an autosomal recessive hereditary disorder that affects copper metabolism causing an excessive accumulation of this chemical in the body (Litwin et al., 2013; Hewlett, 2012; Teleive et al., 2012; Pfeiffer, 2011; Taly, Prashanth, \& Sinha, 2009), primarily in the liver, kidney and brain, producing alterations and liver damage, neurological and psychiatric disorders. It has been reported that the incidence of the disease is one in every 30,000 live births (Moller et al., 2011) and affects both men and women, although the neurological manifestations are more common in male patients.

Regarding the symptoms produced by excess metal in the Central Nervous System (CNS), the most affected areas that show degeneration are the lenticular nucleus, putamen, caudate head, globus pallidus, ventral thalamus, dentate nucleus, midbrain (except for the red nuclei), pons and in some cases there is cerebellar atrophy. It is commonly observed that on magnetic resonance imaging (MRI) these areas are hyperintense on T2, and with the transcranial sonography tecnique, hyperechoic lesions are found (Svetel, Mijajlovi, Tomiet et al., 2012; Huster et al., 2012; Krysiak, Handzlik-Orlik, \& Okopien, 2012; Nagel \& Miralles, 2007; Hitoshi, Iwat, \& Yoshikawa, 1991).

WD presents a wide spectrum of manifestations depending on the areas affected by the deposition of metal which are: the liver form, the neurological and psychiatric forms and the form with predominance of other organs (Roberts, 2011; Xu et al.,
2010; López \& Serrano, 2007; Wilson, Alderman, Burgess, Emslie, \& Evans, 2003). Litwin, Gromadzka, Członkowska, et al. (2012) conducted a retrospective study of 204 cases with WD and found that the most common type is the neuropsychiatric with 105 cases, followed by the liver type with 67, and by the type with predominance of other organs, with 32 of the 204 cases studied.

The neurological form of the disease, is particularly characterized by abnormal movements, postural and intentional tremor, chorea, athetosis, myoclonus, seizures, ataxia, dysarthria, hypophagia, hypersalivation, pyramidal signs and abnormalities of eye movement (European Association for the Study of the Liver-EASL, 2012; Svetel, Mijajlovi, Tomiet, et al., 2012). As the disease progresses it is common to find a more complex clinical picture (Lorincz, 2010).

With respect to the WD neuropsychological profile there is little information at present. The majority of articles, research and scientific texts make a description of the general aspects of the neurocognitive profile (Carta et al., 2012; Birk et al., 2011; Jacob \& Srivatsa, 2011; Levy \& Dubois, 2006).

In a study by Hegde, Sinha, Taly \& Vasudev (2010), where he presented the cognitive profile of twelve patients contrasting it with MRI diagnostic studies and the signs and symptoms reported, a greater impairment was found in motor speed (73\%), verbal working memory and focused and sustained attention (50\%), verbal learning (42\%), processing speed (33\% - 34\%), visual memory and verbal fluency $(25 \%-27 \%)$ and verbal recognition (17\%). 
Schmitt et al. (2011), in a 40 years follow-up study with 36 patients diagnosed with WD reported that $25 \%$ of the patients had neuropsychiatric manifestations where the common symptoms were attention deficit, changes in personality, irritability and hypersomnia. Other studies attribute the changes in mood and personality to a dopamine deficit present in the disease (Litwin, Gromadzka, Członkowska, Poniatowska, \& Poniatowska, 2013; Günther, Villmann \& Hermann, 2011; Schmitt et al., 2011; Popević, Kisić, Đukić, \& Bulat, 2011; Hegde, Sinha, Taly, \& Vasudev, 2010).

With respect to executive functions (EF) and Wilson's disease, there is no conclusive research but there is an evidence that regarding the relationship between frontal lobes and basal ganglia, a relationship can be established with the presence of alterations in the executive functioning (Pladdy, 2007).

The EF is dynamic processes which have a high degree of dependence and is performed by different domains or neural network interconnections that work as a unit involving a set of cognitive skills related to processes of programming, regulation and planning of the necessary behavior to achieve an adequate level of adjustment and problem solving related to various cortical-sub cortical areas of the Central Nervous System for its correct functioning.

Alterations due to damage or injury of its structures and networks result in the presence of low capacity for self-control or self-direction, emotional lability, increased tendency to irritability and excitability, impulsivity, erratic behavior, stiffness and deterioration in self-care and grooming (Lezak, 1995; Verdejo-García y Tirapu-Ustárroz, 2012).

Several studies have shown that executive functions are not totally dependent on the prefrontal cortex, but there is a network of neural interconnections that interact simultaneously involving other areas of the CNS, especially connections with subcortical structures such as basal ganglia (Suchy, 2009; Elliot, 2013).

Additionally, it has been established that there is an interaction between the basal ganglia and other subcortical structures such as the thalamus, subthalamic nucleus and globus pallidus in the conformation and configuration of circuits that interact with the frontal lobe for generating a regulated, controlled and supervised behavior of executive functions (Verma, Patil, \& Lalla, 2012; Verdejo \& Bechara, 2010; Suchy, 2009).

Thus, it has currently been established that the Executive Functions depend on the integration of network circuits between the prefrontal cortex and the cortical subcortical structures and not just on one specified region. Lesions in these networks, even without impairment of the frontal lobe, can generate dysexecutive clinical pictures characteristic of prefrontal syndromes as evidenced in progressive supranuclear palsy, multiple system atrophy and Huntington's disease. Therefore, frontostriatal circuits are important in mediating executive function (Elliot, 2013).

This case study aims to show the main changes in cognitive processes presented in a patient with WD, highlighting the alterations or deficits in executive functions and their correlation with neuroanatomical findings obtained by brain MRI. The case study allows us to observe that the impairment in executive functions presented in the WD is not due to injuries in frontal regions as commonly occurs, but to lesions in the intercommunication Prefrontal Cortex-Basal Ganglia-Prefrontal Cortex.

\section{Method}

\section{Desing}

A single case study was carried out, using a descriptive design and following an analytical e mpirical methodology. This methodology was applied to a participant to assess his cognitive functions, focusing the process on his executive functions (Hernández, Fernández, \& Baptista, 2006).

\section{Participant}

Male patient, aged 33, right laterality, with technical professional education level, currently unemployed. He has a history of psychoactive substances consumption, specifically ethanol, with an intake frequency of 3 to 4 times per week which persisted for about 10 years. Consumption is terminated due to the initiation of the major symptoms of the disease. Similarly, there is history of non-abusive social use of cocaine for a year. In 2011 is diagnosed with cerebellar ataxia, initiating a clinical picture of dysarthria and progressive motor impairment.

The patient is admitted to a hospital with a clinical picture of ataxia, dysarthria, hypersalivation, hypophagia and constant mood change. He goes through a multidisciplinary assessment process which found, from the dermatology area, copper accumulation after performing a hyperpigmentation biopsy in lower limbs. In the different diagnostic tests performed by the internal medicine staff, accumulation of this metal is found. The gastroenterology examination gives evidence of liver damage. From the area of ophthalmology, the Kayser-Fleischer rings are found (See Figure 1).

From the neurology area, a brain MRI was performed to the patient. Findings show hyperintense lesions in the basal ganglia (Figure 2) and midbrain (Figure 3), characteristic signs of the disease. The frontal lobes were found intact.

\section{Procedure}

This research was conducted in three phases. In the initial phase, an identification of the case was made at medical and neurological level. Intake interview and signature of the informed consent were carried out. In the second phase, the neuropsychological assessment took place. And in the final phase, the analysis of results and preparation of the final document were done.

\section{Instruments}

Brief Neuropsychological Battery in Spanish, Neuropsi: This is a screening test. In order to carry out its standardization, it was applied to a sample of 800 neurologically intact subjects aged between 16 and 85 years. The sample was divided into four groups according to age and educational level. Reliability was assessed by the test-retest method, with an interval of three months between each application and marking was done by different assessors. Reliability between examiners was 0.89 to 0.95 . This instrument allows assessing a wide range of cognitive functions in patients with psychiatric, geriatric, neurological and various medical problems (Ardila \& Ostrosky, 2012).

Trail Making Test-TMT-Parts A and B: It is considered that Part A measures motor, viso-spatial skills of visual search and sustained attention, while Part B, additionally involves mental flexibility and divided attention. The test-retest reliability varies greatly according to the specific study (0.60 to 0.90 ), 


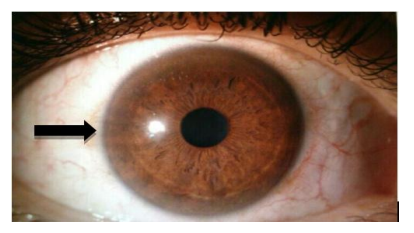

Figure 1.

Kayser Fleischer Ring in the patient.

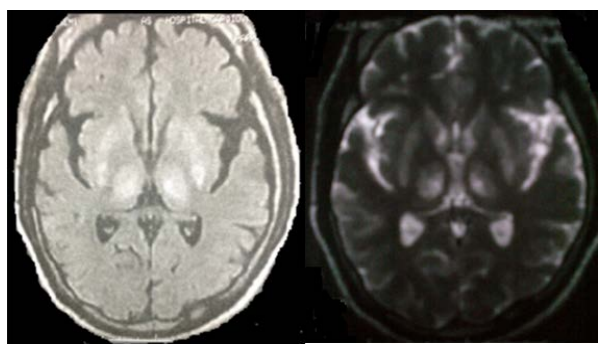

Figure 2.

MRI, hyperintense lesions in basal ganglia.

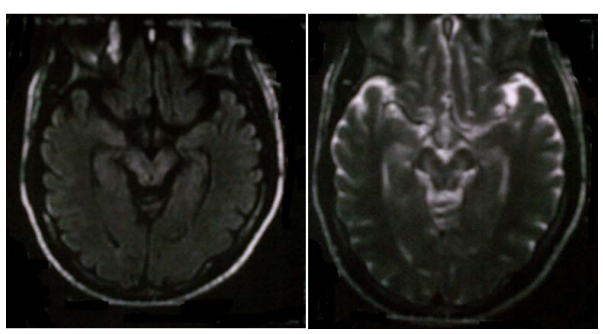

Figure 3.

MRI hyperintense lesions on T2 at midbrain level in patient with WD.

depending on the part or applied version and the pathology (greater variability in schizophrenics, more stability in patients with vascular disease). The temporal stability of the B-A difference is 0.71 . The educational level has a significant influence on the scores, especially in Part B. No gender differences were found. According to studies conducted, there is a significant correlation between the test score (both parts) and the degree of atrophy of the caudate nucleus (Ardila \& Ostrosky, 2012).

Stroop D-Kefs: It is used to assess inhibition in executive functions. The reliability of the test is carried out by the testretest method, being 0.84 . Likewise, it is marked by different assessors and obtains significant correlations (Lopez, Serrano, Llano, Mateos, López, \& Sánchez, 2010).

Wisconsin Card Sorting Test, WCST: neuropsychological test used to assess cognitive flexibility. It is especially sensitive to lesions involving the frontal lobes. The reliability was conducted from a test-retest with a correlation of 0.93 for perseverant responses, 0.92 for perseverant errors, 0.88 for nonperseverant errors, and concurrent validity of $70 \%$ (Scheres et al., 2004).

Visual-verbal Memory Curve by Ardila: A list of twelve words (animals, fruits, and body parts) is presented in three trials. After each trial the subject is asked to tell all the words he can remember. Also, intrusions and perseverations are recorded, as well as primacy and recency effects (Ardila \& Ostrosky, 2012).
Chip Test: the purpose of this test is to assess the understanding of verbal instructions of increasing complexity. The application consists of presenting the chips to the patient and asking him the respective questions which must be made clearly and slowly. Words must not be emphasized. The administration consists of 5 parts, only in Part A and B instruction can be repeated once (Ardila \& Ostrosky, 2012).

Wechsler Adult Intelligence Scale, WAIS III: The Wechsler Intelligence Scale for adults consists of a Verbal Scale and a Performance Scale, so that the application provides three scores: a Verbal IQ, Performance IQ or Manual IQ, and a Full Scale IQ. The subtests used were: block design which measures visual-motor coordination, perception, capacity for analysis, synthesis, logic and reasoning. And the matrices subtest, that was used specifically to determine the attention and planning capacity.

Test of emotion recognition in faces by Baron Cohen (Faces Test) and moral dilemmas of the theory of the mind.

\section{Results}

It was found that the patient showed slowness in the speed of information processing, disinhibition, hypersexuality, persevering behaviors, cognitive rigidity, difficulty to establish or follow sequences, and failure in the development of strategies for achieving goals. Additionally, he presents emotional lability, low frustration tolerance and impairment in the abstraction capacity, in encoding and recalling both verbal and visual stimuli mediated by his executive functioning. On the contrary, his long term memory both episodic and semantic is preserved (Table 1).

These findings account for a clinical picture of dysexecutive syndrome in the patient, which was not the by-product of the damage in the frontal structures, but in the cortico-subcortical connections between basal ganglia and frontal lobes.

\section{Discussion}

The alterations found in the patient's cognitive functions, which correspond to a dysexecutive syndrome, may be associated with possible failure in the connections between basal ganglia and frontal lobes. That is why dysexecutive syndrome is a trigger for alterations involving different cognitive areas (Ardila, 2008).

Results of this study are similar to those reported by Clark, Collazo, Ruenes \& García (2011) who showed that patients with a neurological form of WD had no major impairment in basal ganglia, but they did in their interconnections, showing poor operating performance on executive functioning, memory, visuospatial processing and verbal and abstract reasoning.

Many years ago, the research by Posner \& Raichle (1994), identified the existence of interconnected neural networks to describe attention processes. They suggested that the central control mechanism of the alert system, the orientation system and the executive system forms a dependent circuit, where each one of them is responsible for a specific task in the attention process, but interacting dynamically and integrating into the executive system the interconnected networks of the frontal lobe, the anterior cingulate and the basal ganglia, which makes cognitive functions also interdependent in this process.

In summary, the present case describes a patient who shows neurological involvement both in memory and attention mediated by the executive dysfunction which decreases the possibil- 
Table 1.

Results of neuropsychological test.

\begin{tabular}{|c|c|c|}
\hline \multicolumn{3}{|c|}{ Neuropsy } \\
\hline Score & & Score Normal \\
\hline 89 & & $112-102$ \\
\hline \multicolumn{3}{|c|}{ Trail Making Test A } \\
\hline Time & & Score Normal \\
\hline 164 seconds & & 27 - 32 seconds \\
\hline \multicolumn{3}{|c|}{ Trail Making Test B } \\
\hline Time & & Score Normal \\
\hline 677 seconds & & 56 - 69 seconds \\
\hline \multicolumn{3}{|c|}{ WAIS III } \\
\hline & Direct Score & Normal Score \\
\hline Cubes & $4-8$ & 3 \\
\hline Matrices & $11-12$ & 8 \\
\hline \multicolumn{3}{|c|}{ Wisconsin Card Sorting Test } \\
\hline & Score & Normal Score \\
\hline Trials & 128 & 72 \\
\hline Categories & 1 & 5 \\
\hline Corrects & 62 & 67 \\
\hline Perseverative Errors & $41(32 \%)$ & $(5 \%)$ \\
\hline Conceptual level & 40 & 67 \\
\hline \multicolumn{3}{|c|}{ Ardila`s Verbal Memory Curve } \\
\hline & Score & Normal Score \\
\hline Initial Volume & 5 & $7 \pm 2$ \\
\hline Maximum Volume & 9 & 10 \\
\hline Trials & 10 & 4 \\
\hline Evocation 3 (20) minutes & $9(5)$ & $10(8)$ \\
\hline \multicolumn{3}{|c|}{ Ardila`s Visual Memory Curve } \\
\hline & Score & Normal Score \\
\hline Initial Volume & 5 & $7 \pm 2$ \\
\hline Maximum Volume & 10 & 10 \\
\hline Trials & 3 & 4 \\
\hline Evocation 3 (20) minutes & $9(8)$ & $10(8)$ \\
\hline \multicolumn{3}{|c|}{ Test of emotion recognition in faces } \\
\hline Corrects & & Errors \\
\hline $17 / 20$ & & It—Anger/Boredom—Fear \\
\hline
\end{tabular}

ity of making new effective learning, develops appropriate encoding and recalling strategies, inhibits irrelevant information effectively, holds his attention on the tasks and foster flexibility. All of these impairments can be attributed more to a dysfunction in the cortical-subcortical neuronal interconnection which interferes with the proper functioning of cognitive processes.

The research that gives account of affectations on cognitive functions in WD suggests a deficit in different areas of these operations. However, considering the role of basal gangliaexecutive functions, it is proposed that the main neuropsychological deficit caused in WD lies in executive functions. In similar profiles to the one reported in this study the other cognitive impairments evidenced are secondary to such a deficit.

Although the description of executive functions and neuropsychological involvement made in this study is similar to the descriptions made by other researchers, it differs that it empha- sizes the relationship between cortical and subcortical structures in the conformation of the dysexecutive clinical picture present in WD and points out that the impairments in other domains are secondary to this one.

On the other hand, it is important to note that although the patient has a history of chronic alcohol consumption, and that this condition has some effects on the Central Nervous System -CNS - which, in turn, affects cognitive functions, several studies have found a phenomenon that has been called "deficit recovery following abandonment” (Garrido \& Fernandez, 2004), which refers to a decline in cognitive functions immediately to cessation of the substance. But after overcoming the withdrawal symptoms and having abandoned consumption completely, patients are able to recover their functions within approximately one month. However, at present, the patient in this case study has been in abstinence for more than two years which leads to relating his clinical dysexecutive syndrome directly with WD and copper accumulation in the basal ganglia (Bidaki et al., 2012; Carta, Mura, Sorbello, Farina, \& Demelia, 2012; Di Stefano, Lionetti, Rotolo, La Rosa, \& Leonardi, 2012; Castañeda, Ubilluz, Ávalos, Escalante, \& Nicoll, 2002).

Finally, it is important to note that the projections and circuits between and from the basal ganglia to the cortex have been extensively described in the literature. It is now known that in addition to their circuits and projections with the frontal lobes there are also connections with other cortical areas. Target projections of the thalamic nuclei, superior colliculus, reticular formation and pedunculopontine nucleus are located toward the temporal and parietal areas. Furthermore, it has been reported that such nuclei have a strong participation in the modulation of behavior (Peng, Lutsenko, Sun, \& Muzik, 2012; Cheon et al., 2010; Stocco, Lebiere \& Anderson, 2010; Bernal \& Calle, 2007). This explains the wide variety of cognitive symptoms present in the clinical case shown in this article and the dynamism and complexity of executive processes in the CNS.

\section{Acknowledgements}

First, we wish to express our gratitude and appreciation to the patient and his family for allowing documentation of the case, and thus being able to contribute to the scientific community. Second, to the University Hospital La Samaritana, the MD Yamile Sierra, and to the neurologists Jose Hernandez and Pilar Guerrero.

\section{REFERENCES}

Ardila, A. (2008). On the evolutionary origins of executive functions. Brain and Cognition, 68, 92-99. http://dx.doi.org/10.1016/j.bandc.2008.03.003

Ardila, A., \& Ostrosky, F. (2012). Guía para el Diagnóstico Neuropsicológico. México D.F.: Universidad Nacional Autónoma de México.

Bernal, D., \& Calle, J. (2007). Aspectos neuropsiquiátricos de la enfermedad de Wilson y la esclerosis múltiple. Revista Colombiana de Psiquiatría, 36, 126-138.

Bidaki, B., Zare, M., Mirhosseini, M., Moghadami, S., Hejrati, M., Kohnavard, M., \& Shariati, B. (2012). El mal manejo de la enfermedad de wilson como trastorno psicótico. Advanced Biomedical Research, 1.

Birk, L., Horn, N., Dysgaard, T., Vissing, J., Wibrand, F., Jennum, P., \& Ott, P. (2011). Clinical presentation and mutations in danish patients with wilson disease. European Journal of Human Genetics, 19, 
935-941. http://dx.doi.org/10.1038/ejhg.2011.80

Carta, M., Sorbello, O., Moro, M., Bhat, K., Demelia, E., Serra, A., \& Mura, G. (2012). Bipolar disorders and wilson. BMC Psychiatry, 12, 52. http://dx.doi.org/10.1186/1471-244X-12-52

Carta, M., Mura, G., Sorbello, O., Farina, G., \& Demelia, L. (2012). Quality of life and psychiatric symptoms in wilson's disease: The relevance of bipolar disorders. Clinical Practice \& Epidemiology in Mental Health, 8, 102-109.

http://dx.doi.org/10.2174/1745017901208010102

Castañeda, M., Ubilluz, R., Ávalos, C., Escalante, D., \& Nicoll, J. (2002). Enfermedad de wilson: forma nueropsiquiátrica dominante presentación de un caso y su interpretación fisiopatológica basada en resonancia magnética del encéfalo. Revista de Gastroenterología del Perú, 22, 74-80.

Clark, Y., Collazo, T., Ruenes, C., \& García, E. (2011). Detección de cambios conformacionales y mutaciones en el exón 8 del gen atp7b en pacientes cubanos con la enfermedad de wilson. Biotecnología Aplicada, 28, 83-86.

Cheon, J., Kim, I., Seo, J. K., Ko, J. S., Lee, J. M., Shin, C., Kim, W. S., \& Yeon, K. M. (2010). Clinical application of liver MR imaging in wilson's disease. Korean Journal of Radiology, 11, 665-672. http://dx.doi.org/10.3348/kjr.2010.11.6.665

Di Stefano, V., Lionetti, E., Rotolo, N., La Rosa, M., \& Leonardi, S. (2012). Hypercalciuria and nephrocalcinosis as early feature of wilson disease onset: Description of a pediatric case and literature review. International Monthly Journal in the field oh hepatology, 18, 1-4. http://dx.doi.org/10.5812/hepatmon.6233

Elliott, R. (2013). Executive functions and their disorders. British Medical Bulletin, 65.

European Association for the Study of the Liver (2012). Easl clinical practice guidelines: Wilson's disease. Journal of Hepatology, 56, 671-685.

Garrido, M., \& Fernández, S. (2004). Déficit neuropsicológicos en alcohólicos: Implicaciones para la seguridad vial. Revista de Neurologia, 38, 277-283.

Günther, P., Villmann, T., \& Hermann, W. (2011). Event related potentials and cognitive evaluation in wilson. Journal of Neurological Sciences, 28, 79-85. http://www.jns.dergisi.org/text.php3?id=423

Hegde, S., Sinha, S., Taly, A., \& Vasudev, M. (2010). Cognitive profile and structural findings in wilson disease: A neuropsychological and MRI-based study. Neurol India, 58, 708-713.

http://dx.doi.org/10.4103/0028-3886.72172

Hernández, R., Fernández, C., \& Baptista, P. (2008). Metodología de la investigación (4th ed.). México, México: Mc Graw Hill.

Hewlett, A. (2012). Handbook of liver disease (3rd ed., pp. 230-244).

Hitoshi, S., Iwata, M., \& Yoshikawa, K. (1991). Mid-brain pathology of wilson. Journal of Neurology, Neurosurgery, and Psychiatry, 54, 624-626. http://dx.doi.org/10.1136/jnnp.54.7.624

Huster, D., Kühne, A., Bhattacharjee, A., Raines, L., Jantsch, V., Noe, J., Caca, K., \& Lutsenko, S. (2012). Diverse functional properties of wilson disease atp7b variants. Gastroenterology, 142, 947-956. http://dx.doi.org/10.1053/j.gastro.2011.12.048

Jacob, R., \& Srivatsa, V. (2011). Wilson's disease presenting with psychosis. Asian Journal of Psychiatry, 4, 68-69. http://dx.doi.org/10.1016/S1876-2018(11)60261-X

Krysiak, R., Handzlik-Orlik, G., \& Okopien, B. (2012). Endocrine symptoms as the initial manifestation of wilson. The Yale Journal of Biology and Medicine, 85, 249-254.

Lezak, M. D. (1995) Neuropsychological assessment. Nueva York: Oxford University Press.

Levy, R., \& Dubois, B. (2006). Apathy and the functional anatomy of the prefrontal cortex-Basal ganglia circuits. Cerebral Cortex, 16, 916-928. http://dx.doi.org/10.1093/cercor/bhj043

Litwin, T., Gromadzka, G., Członkowska, A., Poniatowska, M., \& Poniatowska, R. (2013). The effect of gender on brain MRI pathology in wilson's disease. Springer US, 28, 69-75. http://dx.doi.org/10.1007/s11011-013-9378-2

Litwin, T., Gromadzka, G., Szpak, G., Salach, J., Bulska, E., \& Członkowska, A. (2013). Brain metal accumulation in wilson. Journal of the Neurological Sciences, 329, 55-58. http://dx.doi.org/10.1016/j.jns.2013.03.021

Litwin, T., Gromadzka , G., Grzywacz, A. Członkowska, A., Członkowska, A., Członkowski, J., \& Samochowiec, J. (2012). Association of dopamine receptor gene polymorphisms with the clinical course of wilson disease, 73-80. http://dx.doi.org/10.1007/8904 2012 163

López, M., \& Serrano, M. (2007). Enfermedad de wilson: Reporte de un caso y revisión de la literatura. Medicina Interna de México, 23, 458-463.

López, J., Serrano, I., Llano, J., Mateos, J., López, S., \& Sánchez, M. (2010) Utilidad del test de Stroop en el trastorno por déficit de atención/hiperactividad. Revista Española de Neurología, 50, 333-340.

Lorincz, M. T. (2010). Neurologic Wilson's Ds, Lisease. Annals of New York Academic of Science, 1184, 173-187. http://dx.doi.org/10.1111/j.1749-6632.2009.05109.x

Moller, L. B., Horn, N., Joppesen, T. D., Vissing, J., Wibrand, F., Jennum, P., \& Ott, P. (2011). Clinical presentation and mutations in Danish patients with Wilson Disease. European Journal of Human Genetics, 19, 935-941. http://dx.doi.org/10.1038/ejhg.2011.80

Nagel, J., \& Miralles, S. (2007). Enfermedad de Wilson: Comienzo con síntomas psiquiátricos. Hallazgos en resonancia magnética encefálica. Revista Argentina de Radiología, 71, 45-49

Peng, F., Lutsenko, S., Sun, X., \& Muzik, O. (2012). Positron emission tomography of copper metabolism in the atp $7 \mathrm{~b}-1-$ knock-out mouse model of wilson's disease. Molecular Imaging and Biology, 14, 70-78. http://dx.doi.org/10.1007/s11307-011-0476-4

Pfeiffer, R. (2011). Handbook of clinical neurology, 100, 681-709. http://dx.doi.org/10.1016/B978-0-444-52014-2.00049-5

Pladdy, H. (2007). Dysexecutive syndromes in neurologic disease. JNPT, 31.

Popević, M., Kisić, G., Đukić, M., \& Bulat, P. (2011). Work ability assessment in a patient with wilson's disease. Archives of Industrial Hygiene and Toxicology, 62, 163-167.

http://dx.doi.org/10.2478/10004-1254-62-2011-2102

Posner, M. I., \& Raichle, M. E. (1994). Images of mind. New York: Scientific American Library.

Roberts, E. (2011). Wilson's disease. Metabolic Liver Disease, 39, 602604

Scheres, A., Oosterlaan, J., Geurts, H., Morein-Zamir, S., Meiran, N., Schut, H., Vlasveld, L., \& Sergeant, J. (2004). Executive functioning in boys with ADHD: Primarily an inhibition deficit? Archives of Clinical Neuropsychology, 19, 569-594. http://dx.doi.org/10.1016/j.acn.2003.08.005

Schmitt de Bem, R., Araujo, D., Mitiko, M., Reis, E., Werneck, L., \& Ghizoni, H. (2011). Wilson's disease in southern Brazil: A 40-year follow-up study. Clinics, 66, 411-416. http://dx.doi.org/10.1590/S1807-59322011000300008

Stocco, A., Lebiere, C., \& Anderson, J. (2010). Conditional routing of information to the cortex: A model of the basal ganglia's role in cognitive coordination. Psychological Review, 117, 1-64. http://dx.doi.org/10.1037/a0019077

Suchy, Y. (2009). Executive functioning: Overview, assessment, and research issues for non-neuropsychologists. Annals of Behavioral Medicine, 37, 106-116. http://dx.doi.org/10.1007/s12160-009-9097-4

Svetel, M., Mijajlovi, M., Tomi, A., Kresojevi, N., Pekmezovi, T., \& Kosti, V. (2012). Transcranial sonography in wilson's disease. Parkinsonism and Related Disorders, 18, 234-238. http://dx.doi.org/10.1016/j.parkreldis.2011.10.007

Taly, A. B., Prashanth, L. K., \& Sinha, S. (2009). Wilson's Disease: An Indian pespective. Neurology India, 57, 528-540. http://dx.doi.org/10.4103/0028-3886.57789

Teive, H., De Bem, R., Muzillo, D., Deguti, M., Munhoz, R., \& Barbosa, E. (2012). Wilson's disease in the south of brazil: A 40 years follow-up study. Parkinsonism and Related Disorders, 18, S66. http://dx.doi.org/10.1016/S1353-8020(11)70335-2

Verdejo-García, A., \& Tirapu-Ustárroz, J. (2012). Neuropsicología clínica en perspectiva: Retos futuros basados en desarrollos presentes. Revista Neurología, 54, 180-186.

Verdejo, A., \& Bechara, A. (2010). Neuropsicologia de las funciones ejecutivas. Psicothetna, 22, 227-235. 


\section{N. GUTIÉRREZ-ÁVILA ET AL.}

Verma, R., Patil, T., \& Lalla, R. (2012). Acute extrapyramidal syndrome and seizures as heralding manifestation of Wilson disease. Neurology India, 60, 363-364.

http://dx.doi.org/10.4103/0028-3886.98547

Wilson, B., Alderman, N., Burgess, P., Emslie, H., \& Evans, J. (2003). Behavioural assessment of the dysexecutive syndrome (bads). Jour- nal of Occupational Psychology, Employment and Disability, 5, 33-37. Xu, P., Lu, Z., Wang, X., Dosher, B., Zhou, J., Zhang, D., \& Zhou, Y. (2010). Category and perceptual learning in subjects with treated Wilson's disease. PLoS ONE, 5, Article ID: e9635. http://dx.doi.org/10.1371/journal.pone.0009635 